\title{
Grub Density of Lepidiota mansueta (Coleoptera: Scarabaeidae) in Different Habitats of the Majuli River Island of Assam, India
}

\author{
D. PUJARI* and B. BHATTACHARYYA \\ All India Network Project on Soil Arthropod Pests \\ Department of Entomology, Assam Agricultural University, Jorhat 785 013, Assam, India
}

(Received: 29 September 2015; accepted: 2 November 2015)

\begin{abstract}
Grub density of Lepidiota mansueta beetle was assessed in five ecologically different habitats viz., open grassland; open cultivated land; cultivated field near tree; grassland near stream and cultivated land near stream on the basis of soil sampling carried out in five selected villages of the Majuli river island of Assam. Highest mean density of grub $\left(8.0\right.$ and $\left.6.5 / \mathrm{m}^{3}\right)$ was recovered from grasslands near stream, followed by open grassland $\left(4.6\right.$ and $\left.4.7 / \mathrm{m}^{3}\right)$, cultivated field near stream $\left(1.8\right.$ and $\left.1.4 / \mathrm{m}^{3}\right)$, open cultivated field $\left(1.1\right.$ and $\left.1.2 / \mathrm{m}^{3}\right)$ and cultivated field near tree $\left(1.0\right.$ and $\left.1.2 / \mathrm{m}^{3}\right)$ during 2011 and 2012 , respectively. Fortnightly soil sampling conducted in grassland and cultivated land revealed that grubs of L. mansueta were confined in the upper most layer of soil (0-20 cm depth) during summer season (April-September) and moved to deeper soil layers during winter season (October-March). Majority of the grubs (81.83 per cent in grassland and 72.73 per cent in cultivated land) were recorded within the top $20 \mathrm{~cm}$ of soil. However, no grubs were noticed beyond $40 \mathrm{~cm}$ of soil depth.
\end{abstract}

Keywords: white grub, Lepidiota mansueta, habitat, grub density, soil depths.

The phytophagous white grubs are more highly evolved as compared to the scavengers and cause serious concern to agriculturists throughout the world, as their grubs have always existed in nature feeding on roots of both weeds and crops. Being polyphagous, grubs can feed on any root or underground stem (Veeresh, 1988). In India, white grubs attained the status of serious pest of almost all Kharif crops (grown during June-July to September-October) because of revolutionary changes in agricultural practices at the peak of green revolution in the late 60 s and thereafter. Looking to the severity of the damage, this noxious soil pest was recognized as the pest of national importance in 1975 (Raodeo and Deshpande, 1987). Sudden emergence of white grubs as a major threat to several economically important crops of this region may be due to improvements in irrigation facilities, better cultivation practices, introduction of high yielding varieties supported by chemical inputs, bringing larger and larger fallow areas under cultivation, introduction of nontraditional crops, monocropping, denudation of forests for agriculture and industrial purposes and building up resistance populations against several insecticide molecules. Now, white

* Corresponding author; e-mail: dwiban.pujari2004@gmail.com

0238-1249/\$20.00 (C) 2016 Akadémiai Kiadó, Budapest 
grubs have become a challenging subject for the farmers and scientists of North East India and the pest is becoming more and more severe every year as they are spreading to regions where they had not been recorded as a pest in the past. The problem is very serious in nature as they become increasingly difficult pests and merit urgent attention for control.

The superfamily Scarabaeoidea is a distinct group of Coleopetera and alone represents nearly 2500 species from the Indian sub-region to which the majority of the phytophagous scarabs belong (Musthak Ali, 2001). The economically most important subfamilies are Melolonthinae, Rutelinae, Dynastinae and Cetoniinae. The scarabaeid fauna of Assam alone comprises of 43 species representing 21 genera and 6 subfamilies (Bhattacharyya and Baruah, 2012). Out of 43 species, 41 species have been reported for the first time from Assam, India. The most economically important species are Lepidiota mansueta, Lepidiota sp. Indet., Sophrops irridipennis, Apogonia spp., Adoretus spp. The genus Lepidiota is well-known pests of sugarcane and other agricultural crops in Australia (Allsopp, 2010), India (Gupta, 1969; Anonymous, 2011; Bhattacharyya et al., 2015), Indonesia (Suhartawan, 1995), Nepal (Yubak Dhoj, 2006), Papua New Guinea (Kuniata and Young, 1992), South Vietnam (Ranga Rao and Rameshwar Rao, 2013), Kenya (Mutonyi, 2004) and Philippines (Quimio et al., 2001). In India, Lepidiota mansueta has been reported to cause substantial damage in the Ganges basin of Uttarakhand and Uttar Pradesh (Chandel et al., 2015). Of late, L. mansueta had appeared as a severe key pest of many field crops grown in the Majuli, the largest mid-river deltaic island of the world. The tuber damage in potato (Solanum tuberosum), plant damage in sugarcane (Saccharum officinarum) and mung bean (Vigna radiata) and corm damage in taro (Colocasia esculenta) caused by the grubs was 42-48, 15-20, 30-35 and 35-40 per cent, respectively (Bhattacharyya et al., 2015). The abrupt emergence of $L$. mansueta as a major threat to certain economically important crops of this island may be due to intensive cultivation, conversion of fallow lands in to agricultural lands, deforestation as well as overall changes in the climatic scenario (Bhattacharyya et al., 2013). L. mansueta has a biennial life cycle, the first of its kind in North East India. Though it is a biennial white grub species, the third instar grubs were found throughout the year due to mixed population of first year and second year aged grubs of overlapping generations (Bhattacharyya et al., 2015). Moreover, L. mansueta grubs thrive well in wet soil conditions of the Majuli river island and withstand prolonged submergence or flood (Bhattacharyya et al., 2013). The present investigation on grub density of L. mansueta in five ecologically different habitats of the Majuli river island was carried out to explore the information for ecofriendly and effective management of the grubs.

\section{Materials and Methods}

\section{Experimental site: the Majuli river island}

Majuli, the largest inhabited river island of the world, is situated between $26^{\circ} 45^{\prime}$ $\mathrm{N}-27^{\circ} 12^{\prime} \mathrm{N}$ latitude and $93^{\circ} 39^{\prime} \mathrm{E}-94^{\circ} 35^{\prime} \mathrm{E}$ longitude with mean height of $84.5 \mathrm{~m}$ above MSL. The maximum summer temperature varies from $30-35^{\circ} \mathrm{C}$ with a minimum temperature of $12^{\circ} \mathrm{C}$. The average annual rainfall ranges from $200-250 \mathrm{~cm}$ with 80 per cent rel- 
ative humidity. The normal rainy season begins from April-May followed by the highest rains from July to September. The dry season with slight or no rain occurred in December, January, February and March. The virgin low land grasslands (sandbars) of the island are slowly being converted to cultivable land by the farmers. Farmers generally prefer to grow winter or Rabi crops (crops grown during October-November to March-April) than summer or Kharif crops (crops grown during June-July to September-October) since, its majority area is inundated with flood during the month of June and July.

\section{Densities of L. mansueta grub in different habitats}

Density of third instar grubs of L. mansueta was assessed in five different habitats (area: $0.5 \mathrm{ha}$ ) and the background information of each habitat is given in Table 1. The above-mentioned five habitats were selected each from five L. mansueta endemic villages, viz. Bhokotchapori Majgaon, Kuli chapori, Korotipaar, Bhimpara and Podumoni. Soil sampling was carried out fortnightly in the month of August during 2011 and 2012. Fortnightly sampling was averaged to monthly population. A sample consisted of randomly digging one cubic meter of soil pit ( $1 \mathrm{~m}$ long $\times 1 \mathrm{~m}$ width $\times 1 \mathrm{~m}$ deep $)$ with the help of spade and the numbers of grubs present per pit was recorded. Each month ten numbers of samples were taken from each habitat.

\section{Grub density of L. mansueta grub at different soil depths}

Two different habitats, viz. uncultivated grassland and cultivated field located in Bhimpara village (area: 0.5 ha) were selected for the study. Fortnightly soil sampling was carried out starting from April, 2012 to March, 2013. The fortnightly sampling was

\section{Table 1}

Description of five habitats sampled during 2011-2012

\begin{tabular}{|c|c|}
\hline Ecosystems & Description \\
\hline Open grassland & $\begin{array}{l}\text { Flowing landscapes of open areas where grasses are the dominant vegetation. The dom- } \\
\text { inant grasses grown in this habitat are Elusine indica Phragmites karka, Arundo donax, } \\
\text { Hemarthria pratesse, Saccharum spontaneum, Chrysopogon aciculatus, Imperata cylin- } \\
\text { drical, Erianthus ravennae, Cynodon dactylon, Themeda arundinacea, Vetiveria } \\
\text { zizniodes etc. }\end{array}$ \\
\hline $\begin{array}{l}\text { Open cultivated } \\
\text { field }\end{array}$ & $\begin{array}{l}\text { Open landscape free from trees and shrubs and used for growing green gram crop } \\
\text { (mid-September to mid-December) }\end{array}$ \\
\hline $\begin{array}{l}\text { Grassland near } \\
\text { water source }\end{array}$ & $\begin{array}{l}\text { Grassland near stream; generally submerged during rainy season (June-July). The dom- } \\
\text { inant grasses grown in this habitat are same as open grassland. }\end{array}$ \\
\hline $\begin{array}{l}\text { Cultivated field } \\
\text { near water source }\end{array}$ & $\begin{array}{l}\text { Cultivated field near stream; generally submerged during rainy season (June-July); used } \\
\text { for growing green gram during mid-September to mid-December }\end{array}$ \\
\hline $\begin{array}{l}\text { Cultivated field } \\
\text { near trees }\end{array}$ & $\begin{array}{l}\text { Cultivated field near sheltering or flight trees of adult L. mansueta beetles. The dominant } \\
\text { sheltering or flight trees in this habitat are ber (Ziziphus mauritiana) and chebulic myro- } \\
\text { balan (Terminalia chebula). }\end{array}$ \\
\hline
\end{tabular}


averaged to monthly population to better understanding of population trend of grubs over the entire study period. In each sampling period, ten numbers of pits were dug out at four different depths $(0-10,11-20,21-30$ and 31-40 cm area) of soil with a diameter of one square meter area. The sampling depths were measured with a wooden meter scale to the nearest $\mathrm{cm}$ across the pit level with the ground surface. Grub stages with regards to different instars of L. mansueta were not separated since the first instar grubs were often overlooked due to their small size; however second and third instars were larger in size and readily detected in the soil. Grubs therefore were collectively recorded irrespective of their instars.

\section{Statistical analysis}

Data on population of grubs were transformed by the square root transformation $\sqrt{ }$ $(\mathrm{x}+0.5)$ before analysis of variance (ANOVA) (Gomez and Gomez, 1984).

\section{Results}

\section{Grub density in different habitats}

Experimental results revealed that mean density of L. mansueta grub recovered from grassland near stream $\left(8.0 \pm 0.3\right.$ and $\left.6.5 \pm 0.5 / \mathrm{m}^{3}\right)$, open grassland $(4.6 \pm 0.5$ and $\left.4.7 \pm 0.5 / \mathrm{m}^{3}\right)$ and cultivated land near stream $(1.8 \pm 0.2$ and $1.4 \pm 0.2)$ differed significantly in both the years (Table 2). Grub density registered from open cultivated field $\left(1.1 \pm 0.3\right.$ and $\left.1.2 \pm 0.3 / \mathrm{m}^{3}\right)$ and cultivated field near tree $\left(1.0 \pm 0.2\right.$ and $\left.1.2 \pm 0.3 \mathrm{~m}^{3}\right)$ were found to be at par with each other during 2011 and 2012, respectively. Kuniata and Young (1992) reported that L. reuleauxi grubs survived on some weeds as secondary host plants, viz. Saccharum officinarum, S. spontaneum, Imperata cylindrical, Panicum maximum, Pennisetum purpureum grown abundantly on Ramu River Valley, Papua New Guinea. According to Burns (1926), Dermolepida albohirtum females preferred weedy fields for oviposition. Females of various species of white grubs preferred grass and weeds, as young larvae need plant roots to survive. Moreover, ovipositing females can sense the presence actively growing plants (King, 1985). In case of white grubs, larvae are quite limited in movement, therefore the female must place her eggs in an environment that most suited to young grubs (Litsinger et al., 2002). Bhattacharyya et al. (2011) also reported that among the weed hosts available in Majuli river island, Eleusine indica (a dominant grassy weed) supported the grubs of L. mansueta. Presence of highest numbers of L. mansueta grubs in grassland near stream habitat indicates that availability of sufficient soil moisture favoured eggs laying, hatching, growth and development of different life stages; more specifically the pupal stage. Based on available literature on the genus Lepidiota reflects that most of the white grub species belonging to the genus Lepidiota were found to exist either on the Islands or near the river valley (Bhattacharyya et al., 2015). The grubs of L. stigma has been reported to cause extensive damage to maize in river bed areas having loose sandy soil in some parts of Himachal Pradesh of India (Anonymous, 2011). Two species, 
Table 2

Grub density of L. mansueta in five selected habitats

\begin{tabular}{lcc}
\hline \multicolumn{1}{c}{ Ecosystem } & \multicolumn{2}{c}{ Mean density $( \pm$ S.D. $)\left(\text { no. } / \mathrm{m}^{3}\right)^{*}$} \\
\cline { 2 - 3 } Open grassland & 2011 & 2012 \\
Open cultivated field & $4.6 \pm 0.5$ & $4.7 \pm 0.5$ \\
& $(3.8-5.2)$ & $(4.6-5.4)$ \\
Cultivated field near tree & $1.1 \pm 0.3$ & $1.2 \pm 0.3$ \\
& $(0.8-1.6)$ & $(0.8-1.6)$ \\
Grassland near stream & $1.0 \pm 0.2$ & $(0.8-1.6)$ \\
& $(0.8-1.2)$ & $6.5 \pm 0.5$ \\
Cultivated field near stream & $8.0 \pm 0.3$ & $(6.0-7.2)$ \\
& $(6.0-9.2)$ & $1.4 \pm 0.2$ \\
S. E ${ }_{\mathrm{d}}( \pm)$ & $1.8 \pm 0.2$ & $(1.2-1.8)$ \\
\hline LSD $(0.05)$ & $(1.6-2.0)$ & 0.06 \\
\hline CV $(\%)$ & 0.09 & 0.13 \\
\hline F value & 0.20 & 5.31 \\
\hline
\end{tabular}

* Data were mean of five replications from five fields; figures in parenthesis are in range

$\mathrm{S} . \mathrm{Ed}=$ Standard error of difference; $\mathrm{LSD}=$ Least significant difference $\mathrm{CV}=$ Coefficient of variation

L. alticalceus and L. bidentata have appeared as sugarcane pests near the Ord river irrigation area in Western Australia (Allsopp, 1989). The cane grub, L. reuleauxi was found damaging more than thirty per cent of hybrid sugarcanes at Ramu Sugar Ltd. in Papua New Guinea, which is located in the upper reaches of the Ramu river valley (Kuniata and Young, 1992). Soil moisture is an important factor affecting population dynamics of white grubs (Brown and Gange, 1990). Certain levels of moisture in the soil were found essential for survival and hatching of eggs and also for the survival of the grubs especially in their first instars (Potter and Gordon, 1984). Logan (1997) reported that childers canegrub, Antitrogus parvulus laid most eggs in soil near field capacity, no or very few eggs in soil near wilting point and few eggs in soil above field capacity. Tai Hsien (1965) found that soil moisture at 20-30 per cent field capacity was optimum for egg survival.

During survey, lowest numbers of grubs were recovered from cultivated fields as compared to the grasslands. This may be due to the fact that cultivated fields were often disturbed by ploughing which subsequently exposed the grubs to predatory birds as well as natural death of grubs because of desiccation. During the course of study no significant difference was found between the grub population registered in open cultivated fields and cultivated fields near trees. Field observations on adult emergence reveals that soon after the emergence from ground, L. mansueta adults were settled on some sheltering plants grown abundantly near the breeding grounds at a height of 1.5-2.0 meter. Beetles did not settle on tall trees since they were poor fliers. In certain cases, pairs in copula were also noticed on grasses at a height of only few centimeters from the ground. 
The present finding is in conformity with Lopez (1930), who reported that Leucopholis irrotata preferred to oviposit in fallowed uncultivated fields with short grassy vegetation rather than in standing sugarcane fields. He observed that most of L. irrotata beetles flew within three meter from the ground and the dense vegetation blocked their lateral movement within a fully grown sugarcane field by acting as a physical barrier to flight. However, newly planted field or young ratoon crop could not prevent the lateral movement of the beetles.

\section{Grub density of L. mansueta at different soil depths}

Perusal of data presented in (Figs 1,2) reveals the mean monthly density of L. mansueta grubs at different soil depths both in grassland and cultivated field from April, 2011 to March, 2012. Sampling results exhibited that out of 667 and 297 numbers of grubs recovered from grasslands and cultivated lands, 277 and 108 numbers $(81.83$ and 72.73 per cent) were confined within the top $20 \mathrm{~cm}$ soil depths during summer season (April-September). However, a small proportion of grubs were found to move into the deeper layers of soil (21-30 and 31-40 cm) during winter (October-March). However, not a single grub was observed below $40 \mathrm{~cm}$ soil depths in both grassland and cultivated field. Yubak Dhoj (2006) reported that soil depth up to $20 \mathrm{~cm}$ was most preferable depth for the larval activity scarab beetles in Nepal. Litsinger et al. (2002) also observed that grubs of Anomala humeralis were more abundant within 11-20 cm soil depth and hence routine ploughing and harrowing the soil up to $15-20 \mathrm{~cm}$ depths could expose the grubs to predators. More-

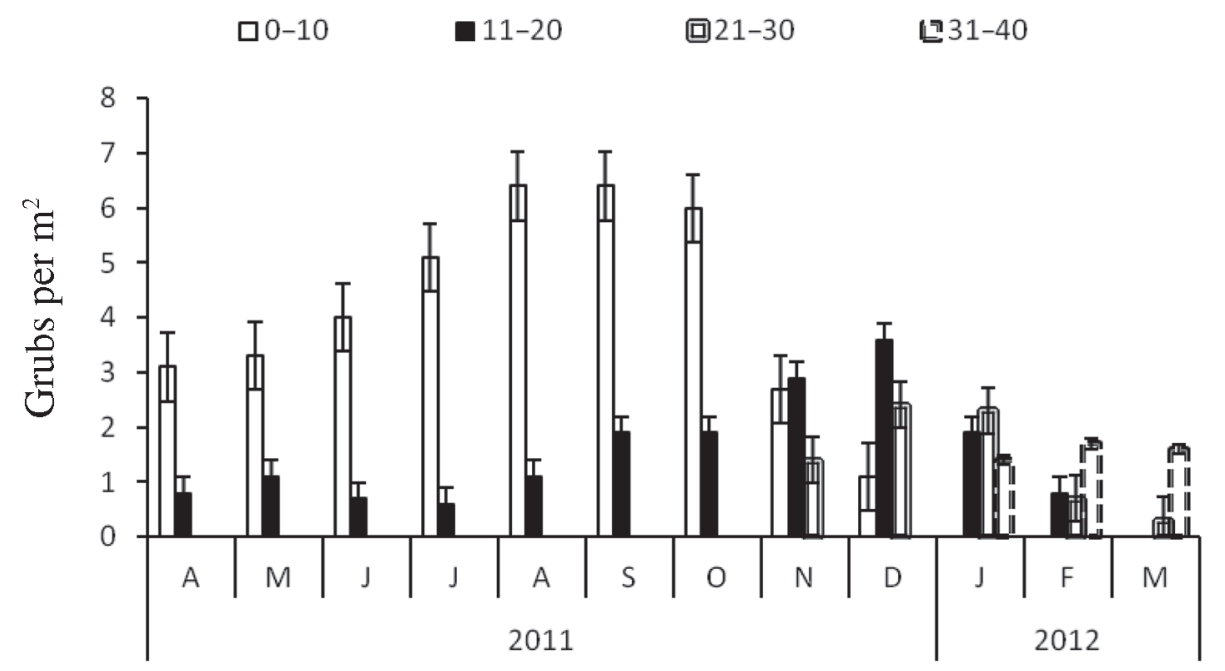

Sampling months

Fig. 1. Mean density of L. mansueta grub at different soil depths sampled in grassland from April, 2011 to March 2012. Bars represent mean grub density per $\mathrm{m}^{2} \pm$ standard error 


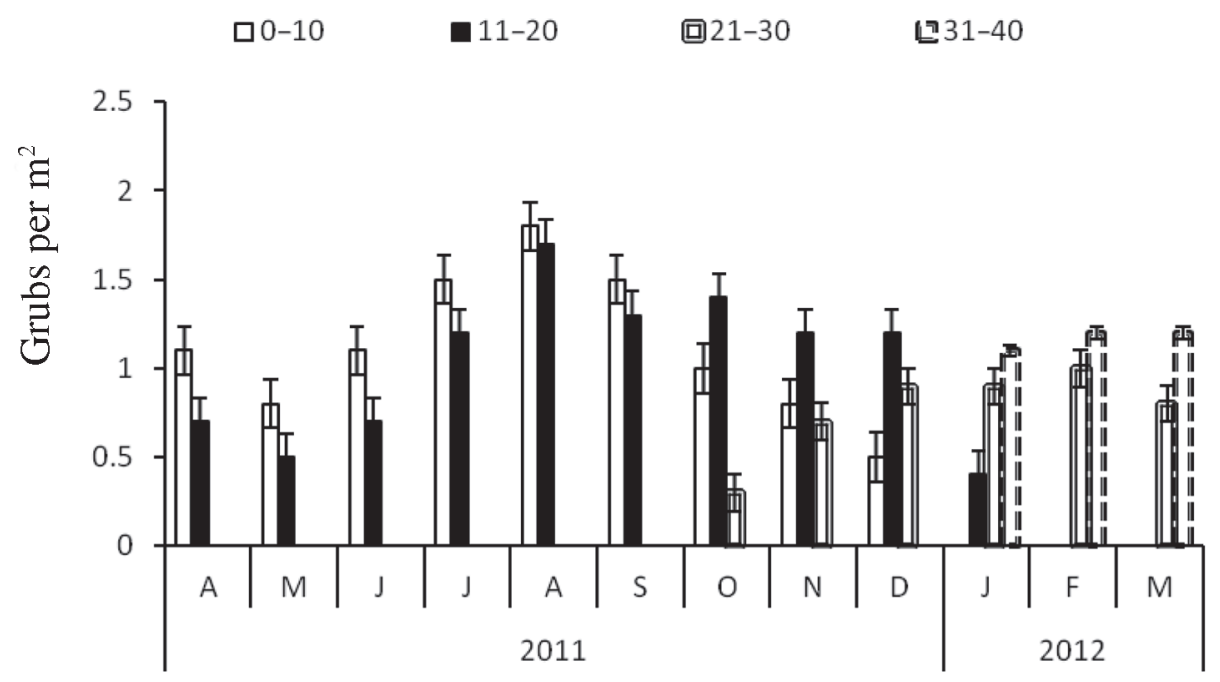

Sampling months

Fig. 2. Mean density of L. mansueta grubs at different soil depths sampled in cultivated field from April, 2011 to March 2012. Bars represent mean grub density per $\mathrm{m}^{2} \pm$ standard error

over, bouts of high rainfall during the summer season (July-August) cause grubs to rise even higher in the soil profile (Bhattacharyya et al., 2015); this has also been observed for five other species of white grub (Litsinger et al., 2002).

Out of five habitats selected, highest density of L. mansueta grub was recorded in the open grassland near water source followed by open grassland. It is noteworthy to mention that L. mansueta has become a major threat to many cultivated crops in Majuli river island because of the massive conversion of grasslands into agricultural lands by the flood and erosion affected farmers without adopting any effective grub management strategies in those habitats. The present investigation reveals that both open grasslands near water source and open grasslands habitat acted as the main reservoir of L. mansueta grubs by providing them ample food, shelter and congenial soil conditions leading to the heavy emergence of beetles during pre-monsoon seasons (April-May). Soil sampling as performed in the present investigation will also help the farmers to identify and locate the breeding grounds of L. mansueta beetle. Since most of the grubs were confined within top $20 \mathrm{~cm}$ soil depth during summer, therefore, the farmers were suggested to accomplish deep summer ploughing at little bit deeper depths by using heavier ploughing equipment like tractor drawn mouldboard plough to expose the grubs to natural enemies. There is an urgent need to educate the farmers about seriousness of the problem (the grub remaining out of sight of the farmers during the entire infestation period), sampling the grubs, recognizing the damage, use of proper thresholds for taking management decisions as well as gain confidence in non-chemical control options by conducting appropriate training programmes for the management of this pest. 


\section{Acknowledgements}

The authors are indebted to the Networking Unit, All India Network Project on Soil Arthropod Pests, Indian Council of Agricultural Research (ICAR), Jaipur, Rajasthan, India for providing the fund and other amenities to carry out the project at Majuli, Assam, India.

\section{Literature}

Allsopp, P. G. (1989): Two new species of Lepidiota Kirby (Coleoptera: Scarabaeidae: Melolonthinae) from Australia with notes on L. noxia Britton. J. Aust. Entomol. Soc. 28, 39-43.

Allsopp, P. G. (2010): Integrated management of sugarcane white grubs in Australia: An evolving success. Annu. Rev. Entomol. 55, 329-349.

Anonymous (2011): Bioecology and management of phytophagous whitegrubs of India. Technical Bulletin-4, All India Network Project on Whitegrubs and Other Soil Arthropods. Indian Council of Agricultural Research, New Delhi, India.

Bhattacharyya, B. and Baruah, A. A. L. H. (2012): Quinquennial report of AINP on white grubs and other soil arthropods. Department of Entomology, Assam Agricultural University Jorhat Centre, pp. 7-10.

Bhattacharyya, B., Bhyan, U., Baurah, A. A. L. H., Pujari, D. and Saud, R. K. (2011): Lepidiota mansueta Burmeister (Coleoptera: Scarabaeidae): a new severe key pest in Majauli Island, Assam. VIIth International Conference on Arthropods: Chemical, Physiological, Biotechnological and Environmental Aspects, September 18-23, 2011, Bialka Tatrzan'ska, Poland.

Bhattacharyya, B., Pujari, D., Handique, G., Baurah, A. A. L. H., Dutta, S. K. and Das, M. (2013): Monograph on Lepidiota mansueta (Coleoptera: Scarabaeidae). Assam Agricultural University, Jorhat.

Bhattacharyya, B., Pujari, D., Bhyan, U., Handique, G., Baruah, A. A. L. H., Dutta, S. K. and Tanaka, S. (2015): Seasonal life cycle and biology of Lepidiota mansueta (Coleoptera: Scarabaeidae): a serious root feeding pest in India. Appl. Entomol. Zool. DOI 10.1007/s13355-015-0349-4.

Brown, V. K. and Gange, A. C. (1990): Insect herbivory below ground. Adv. Ecol. Res. 20, 2-58.

Burns, A. N. (1926): Cane pest combat and control. Queensland Agriculture J. 25, 47 p.

Chandel, R. S., Mathania, M., Verma, K. S., Bhatacharyya, B., Vashisth, S. and Kumar, V. (2015): The ecology and control of potato whitegrub in India. Potato Research 58, 147-164.

Gomez, K. A. and Gomez, A. A. (1984): Statistical Procedures for Agricultural Research, 2nd ed. Wiley-Interscience, John Wiley and Sons, New York. 680 p.

Gupta, K. M. (1969): First record of Lepidiota mansueta Burm. - a new white grub of beetle damaging sugarcane in Uttar Pradesh. Indian sugar 18, 757-758.

King, A. B. S. (1985): Factors affecting infestation by larvae by Phyllophaga spp. (Coleoptera: Scarabaeidae) in Costa Rica. Bull. Entomol. Res. 75, 417-427.

Kuniata, L. S. and Young, G. R. (1992): The biology of Lepidiota reuleauxi Brenske (Coleoptera: Scarabaeidae), a pest of sugarcane in Papua New Guinea. J. Aust. Ent. Soc. 31, 339-343.

Litsinger, J. A., Libetario, E. M. and Barrion, A. T. (2002): Population dynamics of white grubs in the upland rice and maize environment of Northern Mindanao, Philippines. Intern. J. Pest Mgnt. 48, 239-260.

Logan, D. P. (1997): Effect of soil moisture on oviposition by Childers canegrub, Antitrogus parvulus Britton (Coleoptera: Scarabaeidae). Aus. J. Entomol. 36, 175-178.

Lopez, A. W. (1930): Report of the Entomology Department. In: Annual Report of the Philippine Sugar Association, 1929-1930, Manila, Philippines, pp. 145-172.

Musthak Ali, T. M. (2001): Biosystematics of phytophagous Scarabaeidae - an Indian overview. In: G. Sharma, Y. S. Mathur and R. B. L. Gupta (eds): Indian Phytophagous Scarabaeidae and Their Management. Agrobios, India, pp. 5-47.

Mutonyi, J. (2004): White canegrubs: a potential pest challenge to the sugar industry in Kenya. Proc. S. Afr. Sug. Technol. Ass. 78, 549-550. 
Potter, D. A. and Gordon, F. C. (1984): Susceptibility of Cyclocephala immaculata (Coleoptera:Scarabaeidae) eggs and immatures to heat and drought in turf grass. Environ. Entomol. 13, 794-799.

Quimio, G. M., Santiago, D. R., Ceballo, F. A., Benigno, E. A. and Bato, S. M. (2001): Previous accounts of severe grub infestation. In: Management and monitoring of whitegrubs in sugarcane. Published by Philippines Sugar Research Institute (PHILSURIN), pp. 13-14.

Ranga Rao, G. V. and Rameshwar Rao, V. (2013): Handbook on Groundnut Insect Pests Identification and Management. Information Bulletin No. 39, Patancheru, Andhra Pradesh 502 324, India: International Crops Research Institute for the Semi-Arid Tropics, $88 \mathrm{p}$.

Raodeo, A. K. and Deshpande, S. V. (1987): White grubs and their management. Research Bulletin, Marathwada Agricultural University, Parbhani, India, 11, 77 p.

Suhartawan (1995): Mechanical control of the white grub Lepidiota stigma F. at Madukismo sugar estate. Majalah Penelitian Gula 31, 45-53.

Tai Hsien, T. (1965): Studies on the life history of the large chestnut adult, Melolontha melolontha L. Acta Entomol. Sinica 14, 118-129.

Veeresh, G. K. (1988): Whitegrubs. In: G. K. Veeresh and D. Rajagopal (eds): Applied Soil Biology and Ecology. $2^{\text {nd }}$ ed., IBH, New Delhi, pp. 243-282.

Yubak Dhoj, G. C. (2006): White grubs (Coleoptera: Scarabaeidae) associated with Nepalese agriculture and their control with the indigenous entomopathogenic fungus "Metarhizium anisopliae" (Metsch.) Sorokin. Ph.D Thesis, University of Basel, Faculty of Science 
